\title{
Dental Caries Status of 14-16 Year Old Adolescents in Yangsan Area
}

\author{
Bomin Kwon, Ikhyun Bae, Shin Kim, Jiyeon Kim, Taesung Jeong \\ Department of Pediatric Dentistry, School of Dentistry, Pusan National University
}

\section{Abstract}

Although adolescents usually show peculiar aspects in oral health status, there have been not so many studies about it, while there have been innumerable studies for children. This study aimed at evaluating the prevalence of dental caries of adolescents in Yangsan in Republic of Korea, detecting its contributing factors, and distinguishing the high-risk group by epidemiological mass survey. Besides, the significance including early caries lesion in diagnosis criteria was assessed with minimal invasive concept.

This survey was performed on 1,371 adolescents aged 14 to 16 in Yangsan as subject examinees by a single trained examiner. The dental caries status was checked by oral examination at schools and questionnaire survey was accompanied for some relevant risk factors. The data were analyzed to yield the results as follows:

Regarding the caries experience, the DMFT score by WHO criteria with ECL including or not was 4.79 and 3.97 respectively. In both the criteria, female showed higher values and that of high-risk group was almost twice compared with whole examinees by Sic Index.

About pit \& fissure sealed rate, it revealed the tendency that the more sealed teeth, the lower DMFT values. Among the studied risk factors, only the habit of brushing before going to bed showed positive relationship $(p<$ 0.05).

Key words : Adolescents, Dental caries experience, Early caries lesion, High-risk group, Risk factors

\section{I. 서 론}

청소년기는 어린이에서 성인으로 발달해가는 과도기로서, 신 체적, 심리적, 사회적으로 독특한 특성을 보인다. 특히 이 시기 에는 자율성이 증가함에 따라, 부모의 관심이나 지시로부터 독 립하려는 강한 경향이 있고, 이에 따라 식이습관 및 구강위생관 리도 부모의 통제를 벗어나게 된다. 그러나 학업, 교우관계, 외 모 등 다양한 고민에 밀려 구강건강관리에는 소홀해지기 쉽고, 실제로 이 시기에 구강질환이 증가하는 경향이 관찰된다. 이러 한 배경에 반하여 현재까지의 연구는 어린이의 구강질환에 집 중되어 있으며, 청소년 구강건강실태에 대한 파악은 부족한 실
정으로 판단되었다.

청소년기 구강 내 주요 상병으로는 부정교합, 치주질환, 치아 우식증, 치아침식증, 악관절질환 등 다양한 질환들을 들 수 있 으나, 전통적으로 가장 큰 비중을 차지하고 있는 것은 치아우식 증이다. 치아우식이란 산에 의해 치아의 무기질이 탈회되고 치 아 내부의 유기질이 파괴되는 치아조직의 결손 현상으로, 통증 을 야기하고 치아 수명을 단축시키는 대표적인 구강질환이다 ${ }^{1)}$. 1981년 세계보건기구(World Health Organization, WHO) 는 2000년까지 전 세계 12 세 어린이의 평균 우식 경험 영구치 지수를 낮추자는 목표를 세웠고 ${ }^{2}$, 그 결과 세계적으로 치아우식 증은 꾸준히 감소해 왔다 ${ }^{3-5)}$. 그러나 2000년대 이후 치아우식증 
의 감소 폭이 줄어들었으며, 이는 우식 경험치아가 낮은 집단이 증가함과 동시에 우식 경험치아가 많은 집단도 증가한 불균등 한 분포에 의한 것으로 이해되었다6). 따라서 최근에는 구강보건 사업에 있어 우식경험도가 특히 높은 고위험군만을 따로 분 리 - 평가하여, 별개의 대책을 수립하는 것이 그 추세라 할 수 있다.

한편, 치아우식 경험도를 평가하는 이러한 연구들에서 가장 널리 이용되는 우식 진단 기준은 WHO에서 제시한 DMFT in$\operatorname{dex}($ 우식경험 영구치지수)로, 우식(와동 형성 단계), 상실, 처 치 치아 수의 합이닥). 이것은 임상에서 가장 손쉽게 우식 치아 를 평가할 수 있는 입증된 기준이나, 치아 표층의 파괴가 일어 난 경우에만 우식으로 분류한다는 점에 있어 명백한 한계를 가 진다. 최근 치의학은 수복치료에서 최소침습적인 예방치료로 그 중심이 옮겨가고 있으며, 이에 따라 법랑질의 우식와동 형성 단계에 앞서, 백색, 백묵양의 병소로 나타나는 조기 광물질 소 실도 우식 진단에 있어 고려해야 한다는 주장이 제기되었다8). 특히 청소년기는 다수의 영구치가 미성숙 법랑질 상태인 시기 로서, 구강위생상태 여하에 따라서 치아우식증이 급속 진행될 위험이 있어, 초기우식병소(Early caries lesion, ECL)에 대한 평가가 보다 절실하다고 할 수 있다. 이에 대한 조사방법으로 근래에 들어 널리 사용되고 있는 ICDAS-II(International Caries Detection and Assessment System)을 들 수 있으 나, 치과 광원과 3-in-1 syringe가 필수적이므로 본 연구의 현 장 조사에서는 적용이 불가능하였다.

본 연구는 양산시에 거주하는 14-16세 청소년의 치아우식 경 험도와 그 기여요인을 평가하고, 치아우식 고위험군을 파악하 며, 통상적인 $\mathrm{WHO} \mathrm{DMFT}$ 기준에 더불어 초기우식병소 $(\mathrm{ECL})$ 를 포함시켰을 경우에 드러나는 우식경험도의 차이를 살 펴볼 목적으로 시행되었다.

\section{II . 조사 대상 및 방법}

\section{1. 조사 대상}

양산시 소재 4개 중학교에 재학중인 14-16세 청소년 1,371 명을 대상으로, 구내 검사를 통해 치아우식증 상태를 조사하고, 설문조사를 통해 위험 요인을 평가하였다. 조사는 2013년 5월 부터 2013년 8월까지 해당 학교의 보건실에서 이루어졌고, 조 사 대상의 연령 및 성별 분포표는 Table 1 과 같다.

\section{2. 조사 방법}

(1) 예비 조사

현장 방문조사 이전에 본 조사의 대상과 동일한 연령대의 청 소년 구내사진을 통해 치아우식증을 평가하는 훈련을 시행하였 다. 상하악 순·협면 및 교합면이 촬영된 50명의 청소년 구내 사진을 본 연구의 진단기준에 따라 평가하고, 2 주 후에 재평가 하여 그 일치성을 확인하였다.

\section{(2) 구강 검사}

구강검사는 각 학교 보건실에서 1 인의 검사자에 의해 이루어 졌으며, 헤드라이트, 치경, ball-ended explorer를 이용하여 전 치면을 검사하고 기록하였다. 필요한 경우 거즈를 이용하여 음 식물 잔사와 치면세균막 일부를 제거하였다. 진단 기준으로는 통상적인 WHO criteria와 이에 초기우식병소를 포함한 것 두 가지를 병용하였으며, 치면열구전색이 시행된 치아는 별도로 기록하였다. 이 때 초기우식병소는 표면 파괴 양상이 없는 백색 반점 병소가 보이는 경우로 정의하였다.

(3) 설문 조사

예상 위험요인과 치아우식경험도의 연관성을 파악할 목적으 로, 구강검진 현장에서 청소년의 식이습관, 구강위생습관, 치과 방문경험, 체격에 대한 질문을 포함한 설문지 조사를 시행하였 다. 식이습관에는 간식 섭취 빈도와 시기, 구강위생습관에는 양 치질 횟수, 시기, 방법 등이 포함되었다. 그리고 피검자가 기록 한 신장과 체중을 기준으로 $\mathrm{BMI}$ 지수를 산출하여 비만도를 평 가하였다.

\section{(4) 자료 분석}

$\mathrm{WHO}$ 기준과 $\mathrm{WHO}+\mathrm{ECL}$ 기준 각각의 $\mathrm{DMFT}$ index median을 비교하기 위하여 Wilcoxon's test를 시행하였고, 각 집 단 간 차이를 독립 t-test를 통해 분석한 후, multiplicity를 보 정하기 위해 Bonferroni test를 통해 사후분석을 시행하였다. 위험요인과의 연관성 여부는 chi-squared test로 검정하였다. 통계 분석은 윈도우즈용 SPSS 13.0(SPSS Inc., U.S.A.)을 이용하였으며, 모든 통계량의 유의 수준은 0.05 로 하였다.

(5) 윤리적 고려사항

본 연구는 부산대학교 치과병원의 생명윤리심의위원회의 심 사에 따라, 심의면제를 승인받았다.

\section{III. 연구 성적}

Table 1. Distribution of gender and age of the examinees

\begin{tabular}{lcccc}
\hline & & Total $(\%)$ & Boys(\%) & Girls(\%) \\
\hline Total & & $1,371(100.0)$ & $765(55.8)$ & $606(44.2)$ \\
Age(years) & 14 & $316(23.0)$ & $175(22.9)$ & $141(23.3)$ \\
& 15 & $498(36.3)$ & $275(35.9)$ & $223(36.8)$ \\
& 16 & $557(40.6)$ & $315(41.2)$ & $242(39.9)$ \\
\hline
\end{tabular}

\section{1. 치아우식 경험도}

$\mathrm{WHO}$ 기준과 $\mathrm{WHO}+\mathrm{ECL}$ 기준 각각의 $\mathrm{DMFT}$ index에 대 한 통계치가 Table 2에 나타나 있다. WHO 기준으로 진단한 결과 조사대상의 평균 DMFT index는 3.97이었으며, ECL을 
Table 2. DMFT index according to $\mathrm{WHO}$ and $\mathrm{WHO}+\mathrm{ECL}$ criteria

\begin{tabular}{cccc}
\hline & & Median $(\mathrm{R})$ & Means $(\mathrm{SD})$ \\
\hline WHO & & $4.0(18.0)$ & $3.97(3.239)$ \\
Gender & Boys & $3.0(18.0)$ & $3.62(3.074)$ \\
& Girls & $4.0(18.0)$ & $4.41(3.387)$ \\
Age(years) & 14 & $3.0(13.0)$ & $3.53(2.778)$ \\
& 15 & $3.0(16.0)$ & $3.52(3.060)$ \\
& 16 & $4.0(18.0)$ & $4.61(3.523)$ \\
WHO + ECL & & $4.0(20.0)$ & $4.79(3.643)$ \\
Gender & Boys & $4.0(18.0)$ & $4.38(3.436)$ \\
& Girls & $5.0(20.0)$ & $5.32(3.827)$ \\
Age(years) & 14 & $4.0(14.0)$ & $4.18(3.167)$ \\
& 15 & $4.0(16.0)$ & $4.32(3.485)$ \\
& 16 & $5.0(20.0)$ & $5.55(3.896)$ \\
\hline
\end{tabular}

Wilcoxon's test $(p<0.05)$

R: range, SD: standard deviation
포함한 경우는 4.79였다. Wilcoxon's test에 의하면 이 두 기 준에 따른 DMFT index 간에는 유의한 차이가 존재하였다 $(p<$ 0.05). Table 3 은 WHO 기준에 ECL을 포함시켰을 경우에 $\mathrm{DMFT}$ index가 달라지는 피검자의 비율을 나타내었다. 이에 따르면 우식경험도가 높을수록 ECL을 포함시킨 기준에서 DMFT index가 더 증가하는 경향이 관찰되었다.

$\mathrm{DT}, \mathrm{MT}, \mathrm{FT}$ 각각의 비율을 살펴보고, 성별 및 연령별 차이 를 평가한 결과는 Table 4 와 5 에 나타나 있다. WHO 기준 하 에서 DMFT 3.97 중 DT 1.68, MT 0.01, FT 2.28의 분포를 보였으며, 성차는 $\mathrm{DT}$ 와 $\mathrm{MT}$ 에서는 보이지 않았고 $\mathrm{FT}$ 와 $\mathrm{DMFT}$ 에서 나타났다 $(p<0.001)$. 연령 증가에 따른 결과 역시 $\mathrm{FT}, \mathrm{DMFT}$ 에서만 차이를 보였다 $(p<0.001) . \mathrm{WHO}+\mathrm{ECL}$ 기준 하에서 DMFT 4.79 중 DT 2.5, MT 0.01, FT 2.28의 분포를 보였으며, $\mathrm{WHO}$ 기준과 마찬가지로 성별 및 연령별 차 이는 FT, DMFT에서만 나타났다 $(p<0.001)$.

Table 3. Effect of the inclusion of ECL on DMFT index

\begin{tabular}{cccc}
\hline WHO DMFT & Children (\%) & $\begin{array}{c}\text { Number(\%) of WHO DMFT indexs that } \\
\text { did not change after ECL inclusion }\end{array}$ & $\begin{array}{c}\text { Number(\%) of WHO DMFT indexs that } \\
\text { change after ECL inclusion }\end{array}$ \\
\hline 0 & 18.1 & $190(76.6)$ & $58(23.4)$ \\
$1-5$ & 51.0 & $470(67.2)$ & $229(32.8)$ \\
$6-18$ & 30.9 & $263(62.0)$ & $161(38.0)$ \\
Total & 100.0 & $923(67.3)$ & $448(32.7)$ \\
\hline
\end{tabular}

Table 4. Distribution of DT, MT and FT according to WHO Criteria

\begin{tabular}{llcccc}
\hline & & DT & MT & FT & DMFT \\
\hline Total & & $1.68 \pm 2.469$ & $0.01 \pm 0.132$ & $2.28 \pm 2.479$ & $3.97 \pm 3.239$ \\
Gender & Boys & $1.57 \pm 2.377$ & $0.01 \pm 0.125$ & $2.04 \pm 2.394$ & $3.62 \pm 3.074$ \\
& Girls & $1.82 \pm 2.574$ & $0.01 \pm 0.140$ & $2.58 \pm 2.553$ & $4.41 \pm 3.387$ \\
& $p$-value & 0.061 & 0.702 & $<0.001$ & $<0.001$ \\
Age(years) & 14 & $1.61 \pm 2.317^{\mathrm{ab}}$ & $0.00 \pm 0.056$ & $1.92 \pm 1.944^{\mathrm{a}}$ & $3.53 \pm 2.778^{\mathrm{a}}$ \\
& 15 & $1.47 \pm 2.213^{\mathrm{a}}$ & $0.02 \pm 0.184$ & $2.03 \pm 2.304^{\mathrm{a}}$ & $3.52 \pm 3.060^{\mathrm{a}}$ \\
& 16 & $1.90 \pm 2.739^{\mathrm{b}}$ & $0.01 \pm 0.104$ & $2.70 \pm 2.820^{\mathrm{b}}$ & $4.61 \pm 3.523^{\mathrm{b}}$ \\
& $p$-value & 0.014 & 0.079 & $<0.001$ & $<0.001$ \\
\hline
\end{tabular}

Mean \pm S.D, $p$-value calculated by Bonferroni test

$\mathrm{a}, \mathrm{b}$ : The same character means no statistical difference

Table 5. Distribution of DT, MT and FT according to WHO+ECL Criteria

\begin{tabular}{llcccc}
\hline & & DT & MT & FT & DMFT \\
\hline Total & & $2.50 \pm 3.029$ & $0.01 \pm 0.132$ & $2.28 \pm 2.479$ & $4.79 \pm 3.643$ \\
Gender & Boys & $2.32 \pm 2.957$ & $0.01 \pm 0.125$ & $2.04 \pm 2.394$ & $4.38 \pm 3.436$ \\
& Girls & $2.72 \pm 3.106$ & $0.01 \pm 0.140$ & $2.58 \pm 2.553$ & $5.32 \pm 3.827$ \\
& $p$-value & 0.015 & 0.702 & $<0.001$ & $<0.001$ \\
Age(years) & 14 & $2.26 \pm 2.898^{\mathrm{a}}$ & $0.00 \pm 0.056$ & $1.92 \pm 1.944^{\mathrm{a}}$ & $4.18 \pm 3.167^{\mathrm{a}}$ \\
& 15 & $2.27 \pm 2.802^{\mathrm{a}}$ & $0.02 \pm 0.184$ & $2.03 \pm 2.304^{\mathrm{a}}$ & $4.32 \pm 3.485^{\mathrm{a}}$ \\
& 16 & $2.84 \pm 3.261^{\mathrm{b}}$ & $0.01 \pm 0.104$ & $2.70 \pm 2.820^{\mathrm{b}}$ & $5.55 \pm 3.896^{\mathrm{b}}$ \\
& $p$-value & 0.002 & 0.079 & $<0.001$ & $<0.001$ \\
\hline
\end{tabular}

Mean \pm S.D, $p$-value calculated by Bonferroni test

$a, b$ : The same character means no statistical difference 


\section{2. 치아우식 고위험군의 치아우식 경험도}

피검자를 DMFT index 기준으로 내림차순 정렬한 후, 상위 $1 / 3$ 에 해당하는 대상자를 선택하고, 이 집단에 대한 평균 $\mathrm{DMFT}$ 를 계산하여 Significant Caries index(SIC index)를 산출하였당)(Table 6, 7). 그 결과 고위험군의 평균 DMFT는 $\mathrm{WHO}$ 기준 하에서 7.91, $\mathrm{WHO}+\mathrm{ECL}$ 기준 하에서 8.47로 전 체 모집단의 평균치보다 두 배에 가까운 결과를 보였다. WHO 기준 하에서는 성차가 보이지 않았으며, 연령 증가에 따라 $\mathrm{FT}$, $\mathrm{DMFT}$ 는 증가하였다 $(p<0.05) . \mathrm{WHO}+\mathrm{ECL}$ 기준 하에서는 여자가 남자에 비해 높은 FT, DMFT를 나타냈고, 연령 증가에 따라서도 $\mathrm{FT}, \mathrm{DMFT}$ 가 증가하였다 $(p<0.05)$.

\section{3. 치아 별 우식경험률}

치아 별 우식경험률의 비교에서는 하악 제 1 대구치에서 가장 높게 나타났으며, 이어서 상악 제 1대구치, 하악 제 2 대구치, 상악 제 2 대구치의 순이었다. 가장 낮은 치아는 하악전치와 견 치였고, 상악 견치도 유사한 수준을 보였다(Table 8, Fig. 1).

\section{4. 치면열구 전색여부와 DMFT의 상관관계}

전체 피검자의 제 1,2 대구치 중 치면열구 전색이 시행된 치 아의 비율이 Table 9에 나타나 있다. 상하악 간의 차이는 보이 지 않았으나, 제 1 대구치에 비해 제 2 대구치의 전색 비율이 훨 씬 낮은 것으로 관찰되었다.

Table 6. Distribution of SIC Index according to WHO Criteria

\begin{tabular}{llcccc}
\hline \multicolumn{1}{c}{} & \multicolumn{1}{c}{ DT } & MT & FT & DMFT \\
\hline Total & & $3.67 \pm 3.351$ & $0.01 \pm 0.137$ & $4.23 \pm 3.008$ & $7.91 \pm 2.136$ \\
Gender & Boys & $3.71 \pm 3.351$ & $0.02 \pm 0.174$ & $4.06 \pm 3.216$ & $7.79 \pm 2.151$ \\
& Girls & $3.63 \pm 3.207$ & $0.01 \pm 0.094$ & $4.37 \pm 2.813$ & $8.01 \pm 2.123$ \\
& $p$-value & 0.811 & 0.389 & 0.296 & 0.288 \\
Age(years) & 14 & $3.95 \pm 2.921$ & $0.01 \pm 0.110$ & $3.30 \pm 2.357^{\mathrm{a}}$ & $7.27 \pm 1.624^{\mathrm{a}}$ \\
& 15 & $3.66 \pm 3.134$ & $0.03 \pm 0.222$ & $4.18 \pm 2.964^{\mathrm{ab}}$ & $7.87 \pm 1.996^{\mathrm{ab}}$ \\
& 16 & $3.57 \pm 3.469$ & $0.00 \pm 0.067$ & $4.60 \pm 3.179^{\mathrm{b}}$ & $8.18 \pm 2.326^{\mathrm{b}}$ \\
& $p$-value & 0.663 & 0.176 & 0.003 & 0.004 \\
\hline
\end{tabular}

Mean \pm S.D, $p$-value calculated by Bonferroni test

a,b: The same character means no statistical difference

Table 7. Distribution of SIC Index according to WHO+ECL Criteria

\begin{tabular}{llcccc}
\hline & & DT & MT & FT & DMFT \\
\hline Total & & $4.74 \pm 3.479$ & $0.01 \pm 0.121$ & $3.71 \pm 2.931$ & $8.47 \pm 2.528$ \\
Gender & Boys & $4.79 \pm 3.548$ & $0.02 \pm 0.150$ & $3.42 \pm 3.081$ & $8.23 \pm 2.413$ \\
& Girls & $4.69 \pm 3.417$ & $0.01 \pm 0.084$ & $3.99 \pm 2.760$ & $8.69 \pm 2.618$ \\
& $p$-value & 0.741 & 0.44 & 0.026 & 0.036 \\
Age(years) & 14 & $5.03 \pm 3.343$ & $0.01 \pm 0.099$ & $2.90 \pm 2.365^{\mathrm{a}}$ & $7.94 \pm 2.086^{\mathrm{a}}$ \\
& 15 & $4.84 \pm 3.244$ & $0.02 \pm 0.189$ & $3.48 \pm 2.885^{\mathrm{ab}}$ & $8.34 \pm 2.413^{\mathrm{ab}}$ \\
& 16 & $4.58 \pm 3.662$ & $0.00 \pm 0.060$ & $4.16 \pm 3.073^{\mathrm{b}}$ & $8.74 \pm 2.710^{\mathrm{b}}$ \\
& $p$-value & 0.485 & 0.225 & $<0.001$ & 0.018 \\
\hline
\end{tabular}

Mean \pm S.D, $p$-value calculated by Bonferroni test

a,b: The same character means no statistical difference

Table 8. Distribution of DMFT rates by tooth type(\%)

\begin{tabular}{lcccccccccccccccc}
\hline \multirow{2}{*}{ Upper } & Criteria & 7 & 6 & 5 & 4 & 3 & 2 & 1 & 1 & 2 & 3 & 4 & 5 & 6 & 7 \\
& WHO & 21.5 & 44.2 & 5.5 & 5.3 & 0.4 & 5.3 & 2.2 & 2.2 & 4.9 & 0.2 & 5.8 & 5.4 & 46.8 & 22.9 \\
\multirow{2}{*}{ Lower } & W+E & 27.4 & 48.9 & 8.2 & 8.0 & 0.9 & 6.5 & 2.6 & 2.6 & 6.2 & 0.8 & 8.5 & 8.1 & 50.1 & 27.4 \\
& WHO & 40.7 & 62.1 & 6.2 & 1.6 & 0.1 & 0.3 & 0.3 & 0.3 & 0.2 & 0.1 & 1.5 & 6.5 & 62.6 & 42.1 \\
& W+E & 49.4 & 67.0 & 13.1 & 6.4 & 0.1 & 0.3 & 0.3 & 0.3 & 0.2 & 0.2 & 5.5 & 12.9 & 66.7 & 50.4 \\
\hline
\end{tabular}

W+E, WHO+ECL 


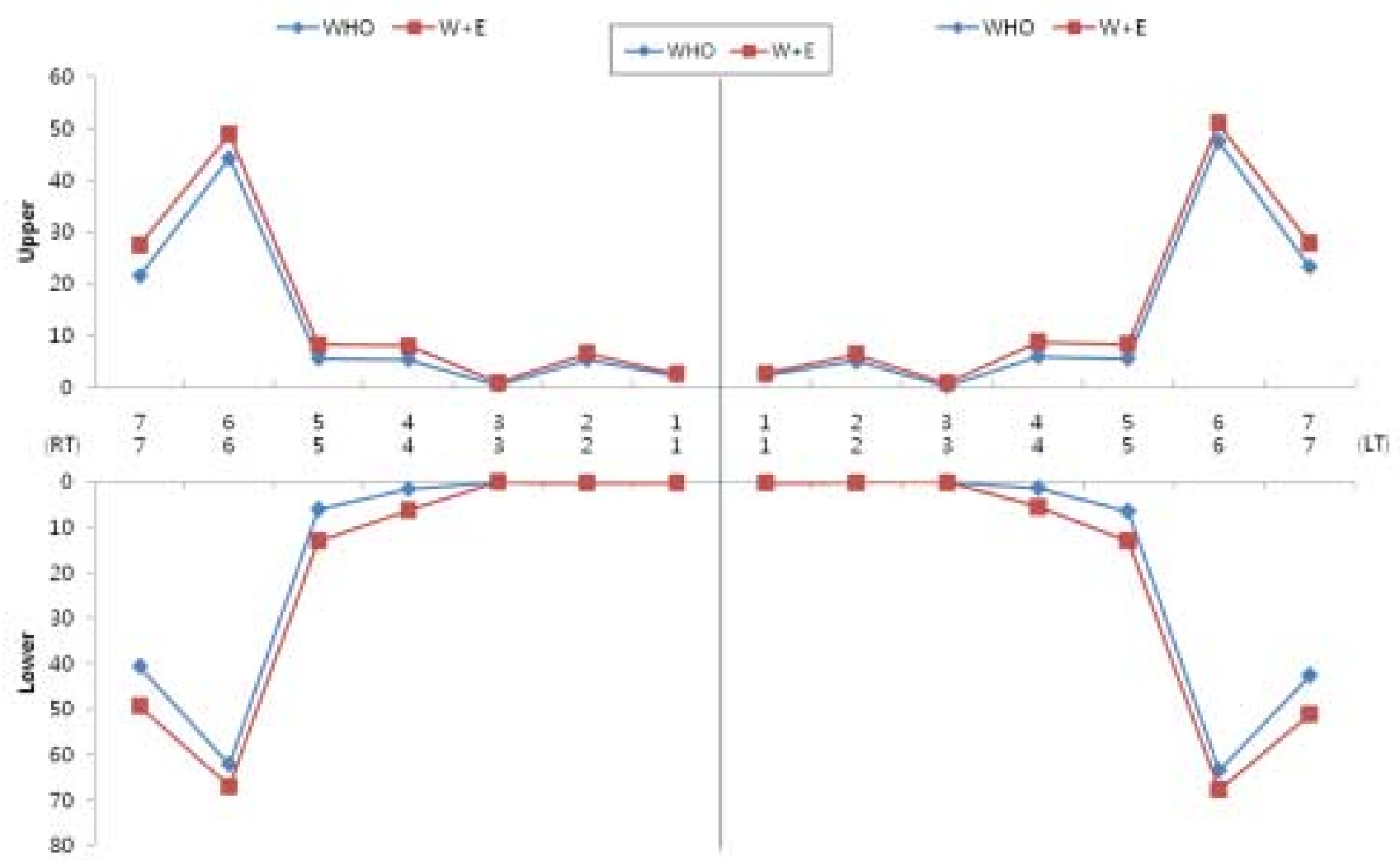

Fig. 1. Distribution of DMFT rates by tooth type(\%).

Table 9. Percentage of molars with pit and fissure sealant $(\%)$

\begin{tabular}{lcccc}
\hline & RM2 & RM1 & LM1 & LM2 \\
\hline Upper & 2.04 & 11.31 & 11.09 & 1.90 \\
Lower & 2.92 & 11.31 & 11.38 & 2.84
\end{tabular}

RM2: Right permanent Second Molar, RM1: Right permanent First Molar LM1: Left permanent First Molar, LM2: Left permanent Second Molar

각 연구대상의 전색치아 개수를 조사하여, DMFT index와 의 연관성을 조사한 결과는 Table 10 에 나타나 있다. WHO 기 준과 $\mathrm{WHO}+\mathrm{ECL}$ 기준 모두에서 전색치아 수가 증가함에 따 라 $\mathrm{DMFT}$ 가 감소하는 경향을 보였다.

\section{5. 예상 위험요인과의 연관성}

(1) 간식 습관 및 구강위생습관

간식을 밤보다 낮에 주로 섭취하는 경우 우식경험도가 높았 으나 그 차이가 유의하지는 않았고, 간식 섭취 빈도에 따른 우 식 경험도 차이는 없었다. 양치질을 하루 3 회 이상 시행하는 경 우 우식 경험도가 낮았으나 그렇지 않은 경우와 비교해서 유의 한 차이는 없었다. 취침 직전에 양치질을 시행하는 경우 우식 경험도가 낮았으며, $\mathrm{WHO}$ 기준에서는 유의성이 없었으나 $(p$ $=0.061), \mathrm{WHO}+\mathrm{ECL}$ 기준으로는 유의한 차이가 보였다 $(p<$ 0.05) (Table 11).

Table 10. The significance values for correlation between sealed to caries experienced teeth

\begin{tabular}{llcc}
\hline & & DMFT by WHO criteria & DMFT by WHO+ECL criteria \\
\hline \multirow{2}{*}{ Number of sealed teeth } & Correlation coefficient & -0.317 & -0.336 \\
& Significant level & $<0.001$ & $<0.001$ \\
\hline
\end{tabular}

$p$-value by Spearman correlation analysis 
Table 11. DMFT according to dietary \& oral hygiene habit

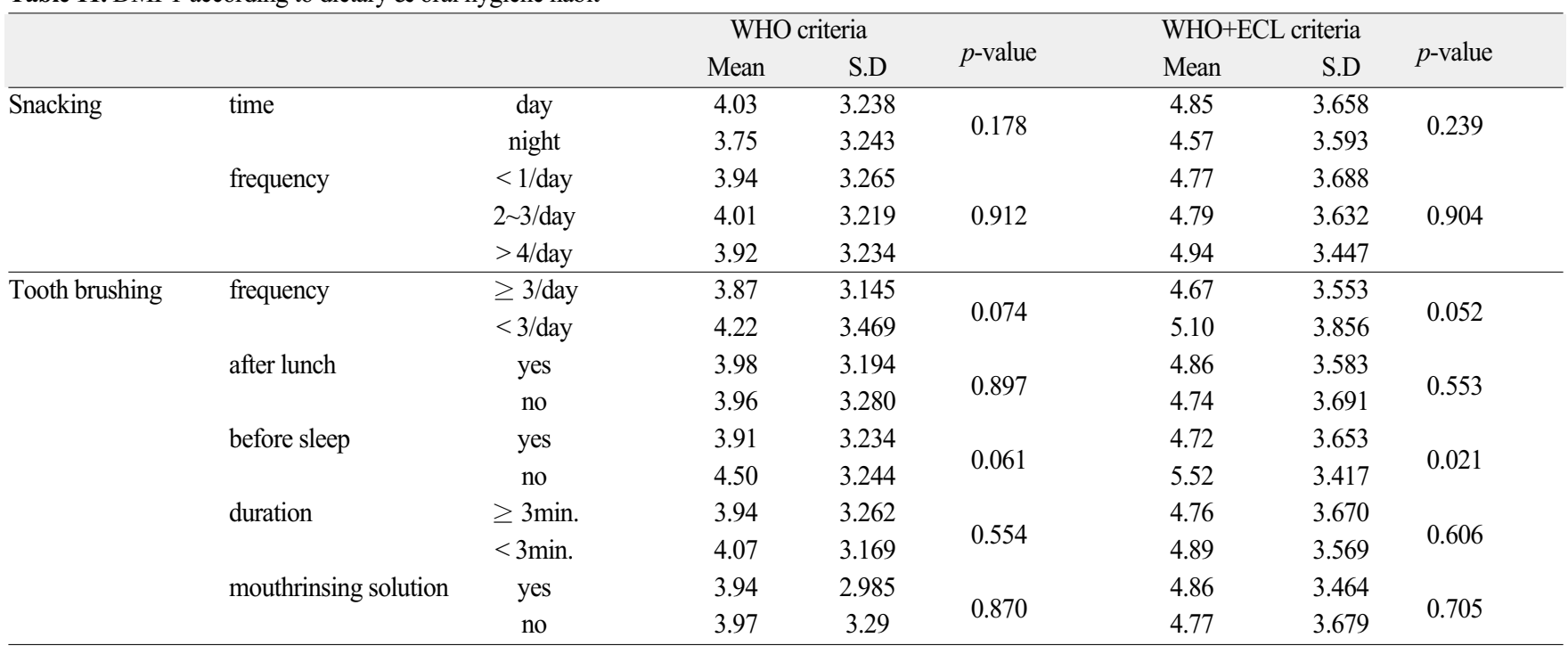

Table 12. DMFT according to dental visit \& BMI

\begin{tabular}{|c|c|c|c|c|c|c|c|}
\hline & & \multicolumn{2}{|c|}{ WHO criteria } & \multirow{2}{*}{$p$-value } & \multicolumn{2}{|c|}{ WHO+ECL criteria } & \multirow{2}{*}{$p$-value } \\
\hline & & Mean & S.D & & Mean & S.D & \\
\hline \multirow[t]{4}{*}{ First dental visit(age) } & $<1 \sim 5$ & 4.03 & 2.743 & \multirow{4}{*}{0.864} & 4.89 & 3.287 & \multirow{4}{*}{0.793} \\
\hline & $5 \sim 10$ & 4.08 & 3.373 & & 4.87 & 3.762 & \\
\hline & $10 \sim 15$ & 3.95 & 3.235 & & 4.88 & 3.673 & \\
\hline & $>15$ & 3.79 & 3.026 & & 4.51 & 3.646 & \\
\hline \multirow[t]{5}{*}{ Recent dental visit(month) } & within 1 & 3.94 & 3.693 & \multirow{5}{*}{0.310} & 4.69 & 4.168 & \multirow{5}{*}{0.617} \\
\hline & within 3 & 4.01 & 3.123 & & 4.89 & 3.375 & \\
\hline & within 6 & 4.36 & 3.286 & & 5.14 & 3.679 & \\
\hline & within 12 & 3.98 & 2.981 & & 4.79 & 3.316 & \\
\hline & none & 3.81 & 3.311 & & 4.69 & 3.785 & \\
\hline \multirow[t]{4}{*}{ BMI } & Underweight $(<18.5)$ & 3.99 & 3.138 & \multirow{4}{*}{0.200} & 4.75 & 3.521 & \multirow{4}{*}{0.302} \\
\hline & Normal(18.5 22.9) & 3.99 & 3.255 & & 4.82 & 3.649 & \\
\hline & Overweight(23 24.9) & 3.27 & 3.123 & & 4.09 & 3.582 & \\
\hline & Obesity $(>25)$ & 3.91 & 3.058 & & 4.78 & 3.503 & \\
\hline
\end{tabular}

(2) 치과 내원 경험과 비만도

처음 치과를 내원한 연령과 최근 치과내원 경험은 모두 우식 경험도와 연관성이 없는 것으로 나타났다. 비만도에 따른 우식 경험도 역시 유의한 차이를 보이지 않았다 $(p>0.05)$ (Table 12).

\section{$\mathrm{V}$. 총괄 및 고찰}

청소년기는 영구치열이 완성되는 시기로, 이 시기에 새로 맹 출한 영구치를 건강하게 유지하는 것은 평생 구강건강에 중대 한 영향을 미친다. 구강건강을 저해하는 대표적 질환에는 치주 질환과 치아우식증이 있으며 ${ }^{10)}$, 어린이와 청소년에서 가장 높은 비중을 차지하고 있는 것은 치아우식증이다 ${ }^{11)}$.
치아우식증은 치아 표면에서 연속적으로 일어나는 탈회와 재 광화의 균형이 무너지는 경우 발생하며, 무증상 병소에서 초기 비와동성 병소를 거쳐 치질이 붕괴되는 명백한 우식 병소로 진 행된다 ${ }^{12)}$. 이 때 탈회가 막 시작된 초기우식병소는 적절한 환경 하에서 수복 시술없이 재광화가 가능하며 ${ }^{13)}$, 방치할 경우에는 통증 및 치질파괴를 동반하는 깊은 우식 병소로 진전될 수 있 다. 특히 청소년의 구강 내에는 맹출 직후의 영구치가 다수 존 재하며, 이는 타액에 의한 맹출 후 광화가 일어나기 전 상태이 므로, 우식 진행 속도가 매우 빠르다. 따라서 치아우식증을 진 단할 때 초기 비와동성 우식 병소를 그 기준으로 삼을 필요가 있다 ${ }^{12)}$. 이러한 경향에 따라 최근에는 ICIDAS, Laser fluorescence, digital imaging fiber-optic trans-illumination, quantitative light-induced fluorescence 등 다양한 방법을 
통해 초기 우식 병소를 탐지하고 있다. 그러나 다수의 인구집단 을 대상으로 하는 역학조사의 경우에는 이 중 용이하게 적용할 수 있는 것이 없어, 여전히 와동성 병소만을 우식의 범주로 진 단하는 WHO 기준을 사용하는 경우가 대부분이다. 이에 본 연 구에서는 시진으로 판단할 수 있는 초기우식병소의 진단 기준 을 설정하고 통상적인 $\mathrm{WHO}$ 기준과 병용하여 조사를 실시함으 로써 역학조사의 한계점을 보완하고자 노력하였다. 그 결과 통 상적인 $\mathrm{WHO}$ 기준과 비교하여, 초기우식병소를 우식치아에 포 함시킨 경우, 우식경험도가 유의하게 증가하는 것으로 드러났 으며, 우식경험도가 높을수록 그 차이는 더 벌어졌다. 물론 초 기우식병소를 우식 진단에 포함시키는 경우 훨씬 긴 검사시간 이 필요하고 그 진단기준이 아직 명확하지 않다는 문제가 있다. 그러나 제한적이나마 다수 청소년의 초기우식병소의 유병률을 파악하고, 그 실체에 좀 더 접근할 수 있다는 점에 있어서 이 조 사방법의 의의가 있다고 할 수 있다.

이번 조사 대상이었던 양산시 거주 14-16세 청소년의 경우, 남자에 비해 여자에서 우식경험도가 높게 나타났는데, 이는 2012년도에 시행된 국민구강건강실태조사 결과와 일치하는 결 과이다 ${ }^{14)}$. 이러한 경향은 여자가 남자에 비해 우식 유발성의 탄 수화물 섭취 빈도가 높으며, 타액 분비량이 적은 것에서 그 원 인을 찾아볼 수 있다. 또한 사춘기에 급격히 증가하는 여성호르 몬이 치아우식증의 발생에 영향을 미친다는 가설도 있다 ${ }^{15}$.

우식경험치아 지수는 3.97 로 국민구강건강실태조사의 15 세 평균인 3.26보다는 다소 높은 결과를 보였다. 그런데 우식경험 치아가 전혀 없는 경우가 $18.1 \%$ 인 반면, 6 개 이상인 경우가 $30.9 \%$ 나 되어, 우식경험도의 양극화 현상을 관찰할 수 있었다. 이런 경향은 우식경험도가 인구 집단에서 불균등하게 분포되어 있다는 과거 선학들의 연구와 일치하는 결과였다 ${ }^{16-19)}$. 다양한 예방 시책에 의해 평균 우식경험도가 감소하면서 이러한 비대 칭적 분포가 심화되었으며 ${ }^{18)}$, 인구집단 내에 매우 높은 우식경 험도를 보이는 치아우식 고위험군이 나타나게 되었다. 전체 인 구집단을 대상으로 하는 전통적 예방사업에는 수돗물불소농도 조정사업, 학교불소용액양치사업, 치아홈메우기, 구강보건교육 등이 있는데, 경제성 및 효율성이 떨어지며 특정 집단에 대한 집중이 어렵다는 단점이 있다 ${ }^{20.211}$. 이에 따라 일반적인 구강보 건사업과는 별도로 치아우식 고위험군에 대한 특별관리 시책이 요구되었으며, 고위험군을 판별하기위한 새로운 기준이 필요해 졌다. Significant Caries( $\mathrm{SiC}$ ) index는 2000년도에 Bratthall ${ }^{22)}$ 이 제시한 기준으로, 한 인구집단에서 고위험군의 우식경험도를 측정하는 방법이다. 이것은 전체 조사대상 중 우 식경험치아지수가 상위 $1 / 3$ 에 드는 사람들의 평균 우식경험치 아지수를 따로 측정함으로써, 기존의 DMFT index를 활용하 면서 우식 고위험군에 대한 정보를 제공해 준다 ${ }^{23-24)}$. 1990 년대 후반 평균 $\mathrm{DMFT}$ 가 감소하면서 일부 유럽국가들에서는 $\mathrm{SiC}$ index의 중요성이 강조되기 시작했으며, 우리나라에서는 2002 년도에 이 ${ }^{25)}$ 등이 처음으로 $\mathrm{SiC}$ index를 이용해서 우식경험도 를 조사한 바 있다. 본 연구에서도 SIC index를 이용하여 고위 험군의 $\mathrm{DMFT}$ 를 조사하였는데, $\mathrm{WHO}$ 기준과 $\mathrm{WHO}+\mathrm{ECL}$
기준 모두에서 전체 피검자 평균치보다 두 배 정도 높은 $\mathrm{DMFT}$ index를 보여서, 해당 집단에 대한 특별관리가 필요할 것으로 사료되었다.

또한 본 연구에서는 가장 우식경험도가 높은 치아인 제 1,2 대구치를 대상으로 치면열구전색과 우식경험도 사이의 연관성 을 살펴보았다. 치면열구전색과 우식예방의 관계에 대해서는 많은 연구가 이루어졌으며 이미 그 효과가 입증된 바이다 ${ }^{26-28)}$. 최근에도 제 1 대구치 중 1 개 이상 치면열구전색을 시행한 경우 우식증 유병률이 낮았다고 Berger ${ }^{29)}$ 등이 보고한 바 있다. 본 조사에서도 치면열구전색이 시행된 치아의 수가 많은 개체의 경우 DMFT index가 유의하게 낮은 것이 관찰되어 선행연구 들과 일치하는 결과를 보였다. 그런데 제 1 대구치의 치면열구 전색 비율이 $11.27 \%$ 인 것과 비교하여 제 2 대구치의 비율은 $2.4 \%$ 에 불과하여, 제 2 대구치에 대한 예방사업이 부족하다는 사실을 알 수 있었다. 특히 2012년 10월부터 국가시책에 의해 14 세 이하 어린이에 대한 제 2 대구치 치면열구전색이 보험급여 로 전환되었으므로, 이에 대한 적극적 홍보활동을 통해 제 2대 구치의 전색률을 높여야 할 것이다.

치아우식증의 적절한 관리를 위해서는 그 위험요인을 규명하 고 이를 제거하는 것이 선결 요건이다. 치아우식증과 연관되었 다고 제시되는 일반적 위험요인에는 섭식습관, 구강위생습관, 치과의료 이용행태 등이 존재한다 ${ }^{30-31)}$. 본 연구에서도 해당 항 목에 대한 설문조사를 실시하여 개인의 우식경험도와 연관성을 평가해 보았는데, 간식섭취습관과 양치질 습관, 치과 내원 경험 의 항목 모두에서 유의한 차이가 존재하지는 않았다. 다만 취침 직전 양치질을 시행하는 경우에는 $\mathrm{WHO}+\mathrm{ECL}$ 기준 하에서 우식 경험도가 유의하게 낮은 것으로 나타났다. 이는 구강위생 상태와 치아우식 유병률 사이에 명확한 관계가 존재하지 않는 다고 보고한 Reisine 등 ${ }^{22}$ 의 연구, 치과의료 이용행태와 치아우 식경험도 사이에 유의한 연관성이 없었던 Polk 등 ${ }^{33}$ 의 보고와 유사한 결과였다.

최근에는 위험요인 중 하나로 청소년의 비만 문제 또한 고려 되고 있는데, 비만 환자의 식이습관에 그 원인이 있다. 비만은 체내에 지방이 과도하게 축적된 상태를 의미하며, 유전적 요인, 내분비 요인보다는 식이습관 등의 생활양식에 의해 발생한다 ${ }^{34)}$. 비만환자가 다량 섭취하는 설탕이 함유된 정제식품은 치아우식 증의 발생원인이므로 ${ }^{35)}$, 비만이 우식경험도에 영향을 미치는 결 정인자라는 주장이 제기된 것이다. 이에 비만과 우식경험도 사 이의 연관성을 밝히려는 연구 $36-38)$ 가 다수 진행되었으나 그 결과 는 매우 다양하여, 아직까지는 명확한 상관관계가 입증되지 못 하였다. 본 연구에서도 신장과 체중을 이용한 $\mathrm{BMI}$ 지수를 통해 우식경험도와의 연관성을 조사하였으나, 유의한 차이는 보이지 않았다. 위와 같이 이번 연구에서는 예상했던 위험요인과 우식 경험도 사이에 주목할 만한 상관관계가 드러나지는 않았으며, 보다 유의한 위험요인을 찾아내기 위한 후속 연구가 필요할 것 으로 생각되었다. 


\section{V. 결 론}

청소년의 치아우식증 유병 상태와 그 기여요인을 평가하고 치아우식 고위험군을 파악할 목적으로, 양산시에 거주하는 1416 세 청소년 1,371 명을 대상으로 임상검사 및 설문조사를 실 시하여 다음과 같은 결론을 얻었다.

통상적인 $\mathrm{WHO}$ criteria를 기준으로 진단을 시행한 결과 조 사대상의 평균 DMFT는 3.97이었다. 우식진단기준에 초기우 식병소를 포함시킨 경우 평균 $\mathrm{DMFT}$ 는 4.79로 유의한 증가 양 상을 보였다 $(p<0.05)$. 성별에 따른 차이는 DT, MT에서는 존재하지 않았고, FT와 DMFT는 여자가 남자보다 높게 조사 되었다 $(p<0.05)$. SIC index를 이용한 치아우식 고위험군의 평균 DMFT는 전체 모집단의 평균보다 두 배 가까이 높은 결 과를 보였다. 치아 별 우식유병률은 하악 제 1 대구치에서 가장 높게 나타났으며, 상악 제 1 대구치, 하악 제 2 대구치, 상악 제 2대구치 순으로 그 뒤를 이었다. 치면열구전색률은 제 2대구치 보다 제 1 대구치에서 훨씬 높았으며, 전색치아 개수가 많은 사 람은 DMFT가 유의한 수준으로 낮았다 $(p<0.05)$. 예상 위험 요인 중에서는 자기 직전 양치질을 시행하는 습관만이 유의한 연관성을 나타냈고 $(p<0.05)$, 간식습관, 치과방문경험, 비만 도 등은 유의성이 존재하지 않았다 $(p>0.05)$.

이상의 연구 결과를 통해, 초기우식병소를 우식 진단기준에 포함시키는 것의 의의를 알 수 있었다. 또한 치아우식 고위험군 에 대한 집중관리 및 적극적인 제 2 대구치 치면열구 전색사업 이 필요할 것으로 판단되었다.

\section{References}

1. Kim JB, Kim JH, Paik DI, et al. : Preventive dentistry 3rd edition. KMS, Seoul, 183, 1999.

2. Federation Dentaire International(FDI) : Global goals for oral health in the year 2000. Int Dent $J$, 32:74-77, 1982.

3. Emerich K, Adamowicz-Klepalska B : Trends in dental caries experience among children and adolescents in nothern Poland between 1995 and 2003. Community Dent Health, 27:218-221, 2010.

4. Marthaler TM : Changes in dental caries 19532003. Caries Res, 38: 173-181, 2004.

5. Armfield JM, Spencer AJ : Quarter of century of change: caries experience in Australian children, 1977-2002. Aust Dent J, 53:151-159, 2008.

6. Burt BA : Prevention policies in the light of the changed distribution of dental caries. Acta Odontol Scand, 56:179-186, 1998.

7. World Health Organization : Oral Health Surveys basic Methods. Geneva: World Health Organization, 1997.
8. Biesbrock AR, Chesters RK, Smith SR, et al. : The challenges of validating diagnostic methods relative to a conventional two-year caries clinical trial. $J$ Dent Res, 83:C53-C55, 2004.

9. Mosha HJ, Fejerskov O, Langebaek J, et al. : Caries experience in urban Tanzanian children 1973-84. Scand J Dent Res, 96:385-389, 1988.

10. Kim JB, Choi YJ : Public Health Dentistry 7th. KMS, Seoul, 368, 1998.

11. Kim HJ, Kim S, Jeong TS, et al. : Literature review of international caries detection and assessment system II to oral examination for children. $J$ Korean Acad Pediatr Dent, 38:202-209, 2011.

12. Goran Koch, Sven Poulsen : Pediatric dentistry 2nd edition. Koonja, Seoul, 73, 2011.

13. Norman $\mathrm{OH}$, Franklin GG : Primary preventive dentistry. Prentice Hall. 37-56, 2003.

14. Ministry of Health and Welfare : Analysis of Korea National Oral Health Survey 2012, 2. Gwacheon, 2013

15. Lukacs JR, Largaespada LL : Explaining sex differences in dental caries prevalence: saliva, hormones, and "life-history" etiologies. Am J Hum Biol, 18: 540-555, 2006.

16. Mosha HJ, Fejerskov O, Langebaek J, et al. : Caries experience in urban Tanzanian children 1973-84. Scand J Dent Res, 96:385-389, 1988.

17. Dimitrova MM, Kukleva MP, Kondeva VK : A study of caries polarization in 1-, 2- and 3-year-old children. Folia Med, 42:55-59, 2000.

18. Burt BA : Prevention policies in the light of the changed distribution of dental caries. Acta Odontol Scand, 56:179-186, 1998.

19. Spencer AJ : Skewed distributions-new outcome measures. Community Dent Oral Epidemiol, 25:5259, 1997.

20. Pieovesan C, Mendes FM, Ardenghi TM, et al. : Inequalities in the distribution of dental caries among 12-year-old Brazilian schoolchildren. Braz Oral Res, 25:69-75, 2011.

21. Clarkson J, Watt FG, Rugg-Gunn AJ, et al. : Community participation and global alliances for lifelong oral health for all, 2009. Adv Dent Res, 222-30, 2010.

22. Bratthall D : Introducing the Significant Caries Index together with a proposal for a new global oral health goal for 12-year-olds. Int Dent J, 50:378384, 2000. 
23. Nishi M, Bratthall D, Stjernsward J : How to calculate the significant caries index(Sic index). Sweden;WHO collaborating centre faculty of odontology, Malmo university, 2001.

24. Nishi N, Stjernsward J, Bratthall D, et al. : Caries experience of some countries and areas expressed by the significant caries index. Community Dental Oral Epidemiol, 30:296-301, 2002.

25. Lee YH, Kwon HG : The Significant Caries $(\mathrm{SiC})$ Index of Korean in 2000. J Korean acad of dent health, 28:438-448, 2004.

26. Bonhannan HM : Caries distribution and the case for sealants. J Public Health Dent, 43:200-204, 1983.

27. Heyduck C, Meller C, Splieth CH, et al. : Effectiveness of sealants in adolescents with high and low caries experience. Caries Res, 40:375-81, 2006.

28. Makhija SK, Childers NK, Lauten J, et al. : Evaluation of initial caries score and caries incidence in a public health sealant program: a retrospective study. Pediatr Dent, 28:420-4, 2006.

29. Berger S, Goddon I, Chen CM, et al. : Are pit and fissure sealants needed in children with a higher caries risk?. Clin Oral Investig, 14:613-620, 2010.

30. Fisher-Owens SA, Gansky SA, Platt LJ, et al. : Influences on children's oral health: a conceptual model. Pediatrics, 120:510-520, 2007.

31. Piovesan C, Mendes FM, Ferreira FV, et al. : Socioeconomic inequalities in the distribution of den- tal caries in Brazilian preschool children. J Public Health Dent, 70;319-326, 2010.

32. Reisine ST, Psoter W : Socioeconomic status and selected behavioral determinants as risk factors for dental caries. J Dent Educ, 65:1009-1016, 2001.

33. Polk DE, Weyant RJ, Manz MC : Socioecomic factors in adolescents' oral health: are they mediated by oral hygiene behaviors or preventive interventions?. Community Dent Oral Epidemiol, 38:1-9, 2010.

34. Park SH, Choi BY, Oh HW, et al. : Relationship between diet behavior and dental caries experience among elementary schoolers. J Korean Acad of Dent Health, 34:327-337, 2010.

35. Gustafsson BE : The vipeholm dental caries study: the effect of different levels of carbohydrate intake on caries activity in 436 individuals observed for five years. Acta Odontol Scand, 11: 232-264, 1954.

36. Werner SL, Phillips C, Koroluk LD : Association between childhood obesity and dental caries. Pediatr Dent, 34:23-7, 2012.

37. Costacurta M, Di Renzo L, Bianchi A, et al. : Obesity and dental caries in paediatric patients. A cross-sectional study. Eur J Paediatr Dent, 12:1126, 2011

38. Alm A, Fåhraeus C, Wendt LK, et al. : Body adiposity status in teenagers and snacking habits in early childhood in relation to approximal caries at 15 years of age. Int $J$ Paediatr Dent, 18(3):189-96, 2008. 
국문초록

\title{
양산시 거주 14-16세 청소년의 치아우식증 상태에 대한 조사연구
}

\author{
권보민·배익현·김 신·김지연·정태성
}

부산대학교 치의학전문대학원 소아치과학교실

소아치과 영역에서 영유아와 학령기 어린이에 대한 연구가 활발히 이루어지는 데에 반해, 청소년 구강상태에 대한 파악은 부족한 실정이다. 본 연구는 청소년의 치아우식 상태와 그 기여요인을 평가하고, 치아우식 고위험군을 파악하며, 기존의 우 식진단기준을 재평가해볼 목적으로 시행되었다.

양산시의 14-16세 청소년 1,371명을 대상으로 단일 검사자가 구강검진 및 설문조사를 시행하여 다음과 같은 결과를 얻었다.

평균 우식경험치지수(DMFT)는 $\mathrm{WHO}$ 기준에서 3.97 , 이에 초기우식병소를 포함시킨 경우에는 4.79였고, 그 중 상위 $30 \%$ 에 해당하는 고위험군은 각각 $7.91,8.47$ 로 전체 평균치를 크게 상회했다. 예상 위험요인 중에서는 취침 직전 양치질을 시행하는 습관의 경우에만 연관성을 나타냈다 $(p<0.05)$.

본 조사대상의 우식경험도는 동일연령을 대상으로 한 선행조사에 비해 높은 결과를 보였으며, 초기우식병소와 우식 고위험 군에 대한 보다 집중적인 이해가 요구될 것으로 판단된다.

주요어: 청소년, 치아우식경험도, 초기우식병소, 고위험군, 위험요인 